\author{
I.E. Stas', V.Yu. Chirkova, I.A. Shtobbe \\ Altai State University, Barnaul, Russia \\ (E-mail: varvara.chirkova@gmail.com)
}

\title{
Experimental study of the electrical conductivity of water, dilute aqueous solutions of alkali metal chlorides and alcohols under the electromagnetic field influence
}

\begin{abstract}
The article is devoted to the study of the influence of a high-frequency electromagnetic field on the electrical conductivity of water, aqueous solutions of alkali metal chlorides and dilute aqueous solutions of normal alcohols. A significant increase in the electrical conductivity of water and aqueous solutions under the influence of the electromagnetic field with a frequency varying in the range of $100-200 \mathrm{MHz}$ is found. The effectiveness of the electromagnetic field impact depends on the frequency of the field and the time of its action. The electrical conductivity of water and aqueous solutions of alcohols increases to the greatest extent, more than twice. The effect of field influence on the electrolytes solutions is sufficiently lower and appears only for the solutions with concentrations of less than $0.01 \mathrm{~mol} / \mathrm{L}$. The maximum increase in electrical conductivity of is observed in $10^{-4}-10^{-3} \mathrm{M}$ sodium chloride solutions and is $27-33 \%$. After the termination of the field action, the electrical conductivity of the electrolytes solutions slowly relaxes to the initial values, and the electrical conductivity of water and aqueous solutions of alcohols continues to increase for 7-10 days until a stationary value is established. The observed phenomena can be caused by a change in the structural organization of water as a result of electromagnetic interference.
\end{abstract}

Keywords: water, aqueous solutions, alkali metal chlorides, aqueous solutions of alcohols, specific conductivity, electromagnetic field, frequency, irradiation time.

\section{Introduction}

Water has a number of properties that sharply distinguish it from other liquids, and it is not yet deciphered, extremely flexible and variable structure, depending on the slightest changes in pressure, temperature, presence of impurities and various energy fields. The presence of low-energy hydrogen bonds between water molecules determines its sensitivity to external influences. However, so far, there are no theoretical and experimentally justified models and mechanisms that explain the short-term and long-term effects of energy and information impacts on water. In this connection, the actual task, in our opinion, is the identification of the mechanism of such phenomena, their relation to the structure and properties of water, and electromagnetic field influence on the water and water systems that is not directly related to changes in the chemical composition of water and aqueous solutions.

The repeatedly verified facts show that even small energy impacts and additives of various substances in a very small concentration lead to a significant change in the physicochemical properties of the systems and cause the shifts in the energy parameters of subsequent physicochemical processes tens of times higher than the energy of the activating action passed to the substance [1-4]. Changes in the structural, optical, kinetic, magnetic, and other physicochemical properties of the water systems studied have been recorded [5-11].

The purpose of this work is to study the effect of a high-frequency electromagnetic field with a frequency varying in the range of 100-200 MHz on the electrical conductivity of dilute aqueous solutions of electrolytes (alkali metal halides) and alcohols.

As the objects of investigation, solutions of lithium, sodium, potassium and cesium chlorides were chosen. According to O.Ya. Samoylov [12], the first two ions have positive hydration, and the last two ions have a negative hydration. According to the same theory, chlorine ions are negatively hydrated. Thus, it is possible to estimate the effectiveness of irradiation of solutions with different types of hydration. Solutions with a concentration of $0.001-0.0001 \mathrm{~mol} / \mathrm{L}$ were studied in the work, so that the ion-ion interaction could be neglected.

Also, the solutions of propyl, butyl, and hexyl alcohols of normal structure, distinguished by the length of the hydrocarbon radical representing the hydrophobic part of the alcoholic diphilic molecule, were chosen as the objects of investigation. The structure of water-alcoholic solutions is largely determined by the structure of water and alcohols, as well as by the features of the interaction between the components in the solu- 
tion. It is known that aliphatic alcohols dissolve in water in significant amounts, due to the formation of strong hydrogen bonds with water molecules. Studies show that when certain amounts of alcohol are added to water, the solution stabilization, which is mainly due to the association of particles, as well as the transition of less ordered structures to more ordered ones, is observed. Liquid water consists of areas of a certain structure, called clusters. When adding alcohol, first the voids between the clusters are filled, that leads to their stabilization, and then the molecules of alcohol begin to compete for hydrogen bonds within the clusters. Particularly easily in the structure of water small molecules of alcohol are introduced, which, falling into local molecular formations, retain the spatial arrangement of water molecules [13]. This confirms the fact that when adding alcohol to water, a decrease in the interlayer distances, compared to the same values for water, is observed. With the increasing alkyl radical, a gradual increase in the interlayer distances occurs, which proves the destructive effect of the more voluminous alcohol molecules, which is accompanied by more significant rearrangements of the molecules spatial arrangement in local water formations [14].

Electromagnetic conductivity was chosen as a response to electromagnetic interference. Previous studies have shown a significant increase of electromagnetic conductivity of water exposed to radiation [15]. In addition, previous studies indicate a change in the surface properties of normal structure aliphatic alcohols solutions [16]. The observed changes in the surface tension of these solutions may be a consequence of changes in intermolecular interactions in the volume of the solution. Alcohols are not electrolytes, therefore the electrical conductivity of water in their presence should not change. However, alcohol molecules change the supramolecular organization of water due to the so-called hydrophobic hydration that is an ordering of water structure near the hydrocarbon radical of the alcohol molecule [14]. Since a significant contribution to the electrical conductivity of water is due to the relay mechanism, which depending on a spatial orientation of water molecules, any reorientation of the solvent molecules both due to the addition of molecules of the dissolved substance (alcohol) and due to the external physical action should lead to a decrease in the activation energy of the proton hopping from this place to the next. Therefore, the study of the electrical conductivity of alcohols solutions and its changes as a result of physical effects seems to us a very promising task that allows us to expand our understanding of the physical picture of processes caused by intermolecular interaction.

\section{Method}

Deionized water purified with the deionizer of water WD-301, with an initial specific electric conductivity of $1.4-1.8 \cdot 10^{-4} \mathrm{~S} / \mathrm{m}$ was used in this study. $\mathrm{LiCl}, \mathrm{NaCl}, \mathrm{KCl}, \mathrm{CsCl}$ of the grade «chemically pure», propanol-1 (GOST 6006-78), butanol-1 (TU 6-09-3467) and hexanol-1 (TU 6-09-3499-87) were used. The purity of the alcohols was checked according to the values of the refractive index and surface tension, so the discrepancies between the found and tabulated values did not exceed $0.5-1.0 \%$.

The source of the electromagnetic field was a high-frequency generator G4-119A, which output power was $1 \mathrm{~W}$ and its frequency range was 30-200 MHz. The voltage at the high-frequency electrodes was 20-22 V. A cell of capacitive type was used to irradiation of water, aqueous solutions of electrolytes and alcohols. The cell consisted of a $20 \mathrm{ml}$ teflon beaker, in the center of which an internal high-frequency electrode was located. The high-frequency electrode was a brass rod, isolated with teflon. The outer high-frequency electrode was an aluminum cup, closely fitting to the teflon surface. The electrodes through the bottom of the cup were connected to the generator by means of an high-frequency cable.

The conductometer CC-102/1 with platinum electrodes was used for measuring the electrical conductivity. The electrodes were stored in deionized water and periodically cleaned the surface by washing with dilute $\mathrm{HNO}_{3}$. The cell constant, determined with use of a $0.01 \mathrm{M} \mathrm{KCl}$ solution, was equal to $51 \mathrm{~m}^{-1}$. Before the experiments, the purity of the dishes (a cell, a cup) was checked according to the electrical conductivity of the deionized water.

Aqueous solutions of salts and alcohols were exposed to EMF with a variable frequency in the range of 100-200 MHz with step of 5-10 MHz. Each portion of the solution was irradiated with a field of only one predetermined frequency. The electrical conductivity values were measured every 10-30 minutes, pouring the solution into a conductometric cell.

\section{Results and Discussion}

Earlier, an increase in the specific electric conductivity $(x)$ of water as a result of the ultra-highfrequency electromagnetic waves influence was determined (the frequency range of 30-200 $\mathrm{MHz}$ was studied). The selectivity of the field action is shown. The maximum increase in $æ$ is observed only at certain field 
frequencies equal to 110,150 and $170 \mathrm{MHz}$. The change in frequency by $\pm 1 \mathrm{MHz}$ relative to the indicated values led to a sharp decrease in the effect.

In this paper, kinetic regularities of the field influence on water are investigated. It is established that changes in the electrical conductivity increase gradually to a certain limit, and it is the effect of «saturation». The rate of increase of the effect and the limiting values of $\not$ depend on the frequency of the EMF. The maximum rate of increase in electrical conductivity corresponds to a frequency of $150 \mathrm{MHz}$, and its maximum value is $170 \mathrm{MHz}$. The settling time of $x_{\max }$ also varies depending on the frequency, so that is from 60 minutes for the frequency of $150 \mathrm{MHz}$, to 240 minutes for the frequency of $170 \mathrm{MHz}$ (Fig. 1).

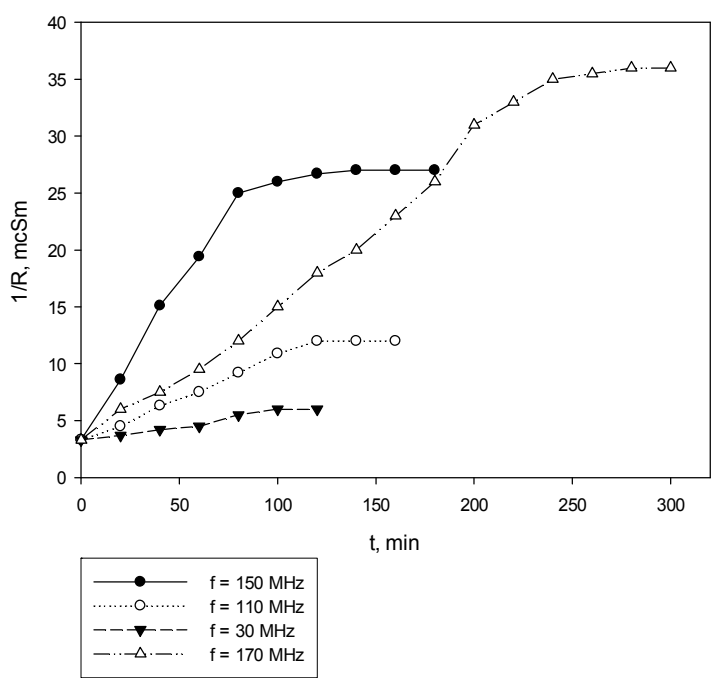

$$
T=296 \mathrm{~K}, \text { cell constant } a=51 \mathrm{~m}^{-1}
$$

Figure 1. Kinetic curves of the change in the electrical conductivity of water under the influence of the fixed frequency electromagnetic field

The values of the electrical conductivity of $10^{-4}-10^{-3} \mathrm{M}$ solutions of $\mathrm{LiCl}, \mathrm{NaCl}, \mathrm{KCl}$ and $\mathrm{CsCl}$ are determined. Figures 2 and 3 shows the experimental values of the conductivity of solutions of these salts. Salts containing positively hydrated ions have a significantly lower electrical conductivity. At the transition from $\mathrm{LiCl}$ and $\mathrm{NaCl}$ to $\mathrm{KCl}$ and $\mathrm{CsCl}$, the conductivity appreciably increases. The lower mobility of $\mathrm{Li}^{+}$and $\mathrm{Na}^{+}$ ions is due to their high degree of hydration and, as a consequence, the large size of the hydrated ions. When the solutions are diluted 10 times, the electrical conductivity of solutions of $\mathrm{LiCl}$ and $\mathrm{NaCl}$ also decreases by approximately 10 times, and for solutions of $\mathrm{KCl}$ and $\mathrm{CsCl}$ conductivity decreases to a lesser degree.

An increase in the electrical conductivity of solutions as a result of EM impact is established. The degree of its increase depends on the nature of the electrolyte and its concentration, field frequency and duration of exposure. Proceeding from the assumption that as a result of the electromagnetic influence, the iondipole interaction can be weakened, which should affect the mobility of the ions, we should expect the greatest influence of the field on solutions of lithium and sodium salts. Indeed, as shown in Figure 2, the maximum increase in the electrical conductivity of millimolar solutions is observed in the case of lithium and sodium chlorides ( 11 and $27 \%$, respectively). For salts of $\mathrm{K}$ and $\mathrm{Cs}$, the change in conductivity is negligible. The field has the least effect on the properties of $\mathrm{KCl}$ solutions.

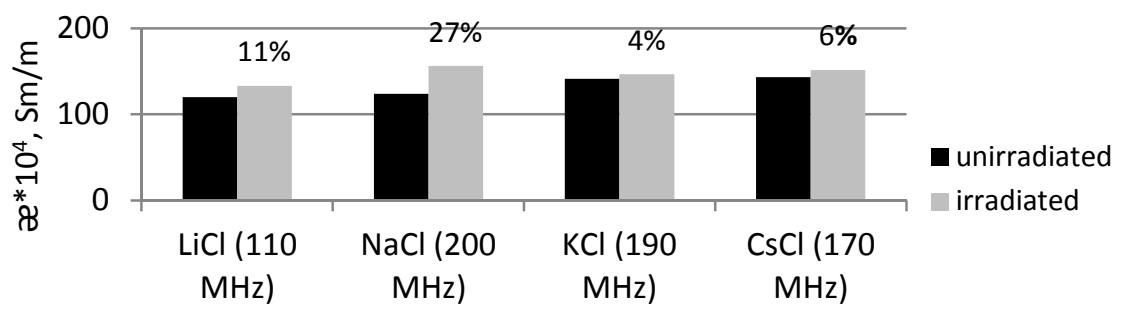

Figure 2. The maximum increase in electrical conductivity of $0.001 \mathrm{M}$ salt solutions as a result of electromagnetic influence $(T=295 \mathrm{~K})$ 
With a decrease in concentration by an order of magnitude, the effectiveness of the electromagnetic action significantly increases (Fig. 3). The effect is most noticed for $\mathrm{NaCl}$.

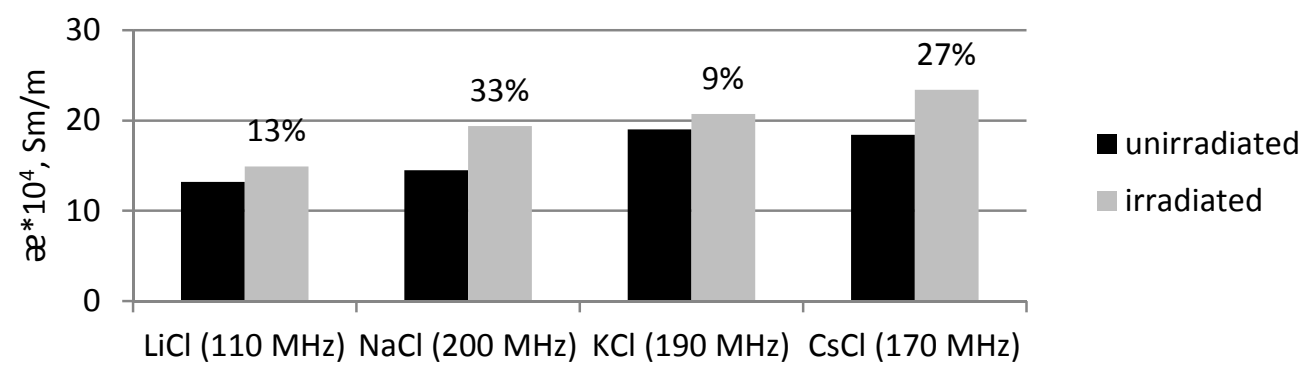

Figure 3. The maximum increase in electrical conductivity of $0.0001 \mathrm{M}$ salt solutions as a result of electromagnetic influence $(T=295 \mathrm{~K})$

As to the nature of the dependence of the electrical conductivity on the frequency of EMF, then clearly expressed maxima are observed for lithium and sodium salts at certain frequencies, while for potassium and cesium salts only small variations of the measured quantity are observed. At $\mathrm{C}=10^{-4} \mathrm{~mol} / \mathrm{L}$ for $\mathrm{CsCl}$, a perceptible maximum of electrical conductivity for a frequency of $170 \mathrm{MHz}$ is observed on this curve. Table 1 lists the frequencies of the electromagnetic field corresponding to the maximum increase in $æ$. They are individual for each electrolyte.

Table 1

\section{Electromagnetic field frequencies corresponding to the maximum increase in electrical conductivity of alkali metal chlorides solutions}

\begin{tabular}{|c|c|c|}
\hline Electrolyte & \multicolumn{2}{|c|}{$\mathrm{f}, \mathrm{MHz}$} \\
\hline $\mathrm{LiCl}$ & 110 & 160 \\
\hline $\mathrm{NaCl}$ & - & 200 \\
\hline $\mathrm{KCl}$ & 100 & 190 \\
\hline $\mathrm{CsCl}$ & 90 & 170 \\
\hline
\end{tabular}

Figures $4 a$ and $4 b$ show the concentration dependences of the effectiveness of the electromagnetic impact in the studied solutions. For the convenience of the graphical representation of the data, the molar conductivity values are given. The electrical conductivity of deci- and centimolar solutions as a result of the field action nearly does not change, and its maximum increase is observed at a concentration of $10^{-4} \mathrm{~mol} / \mathrm{L}$.

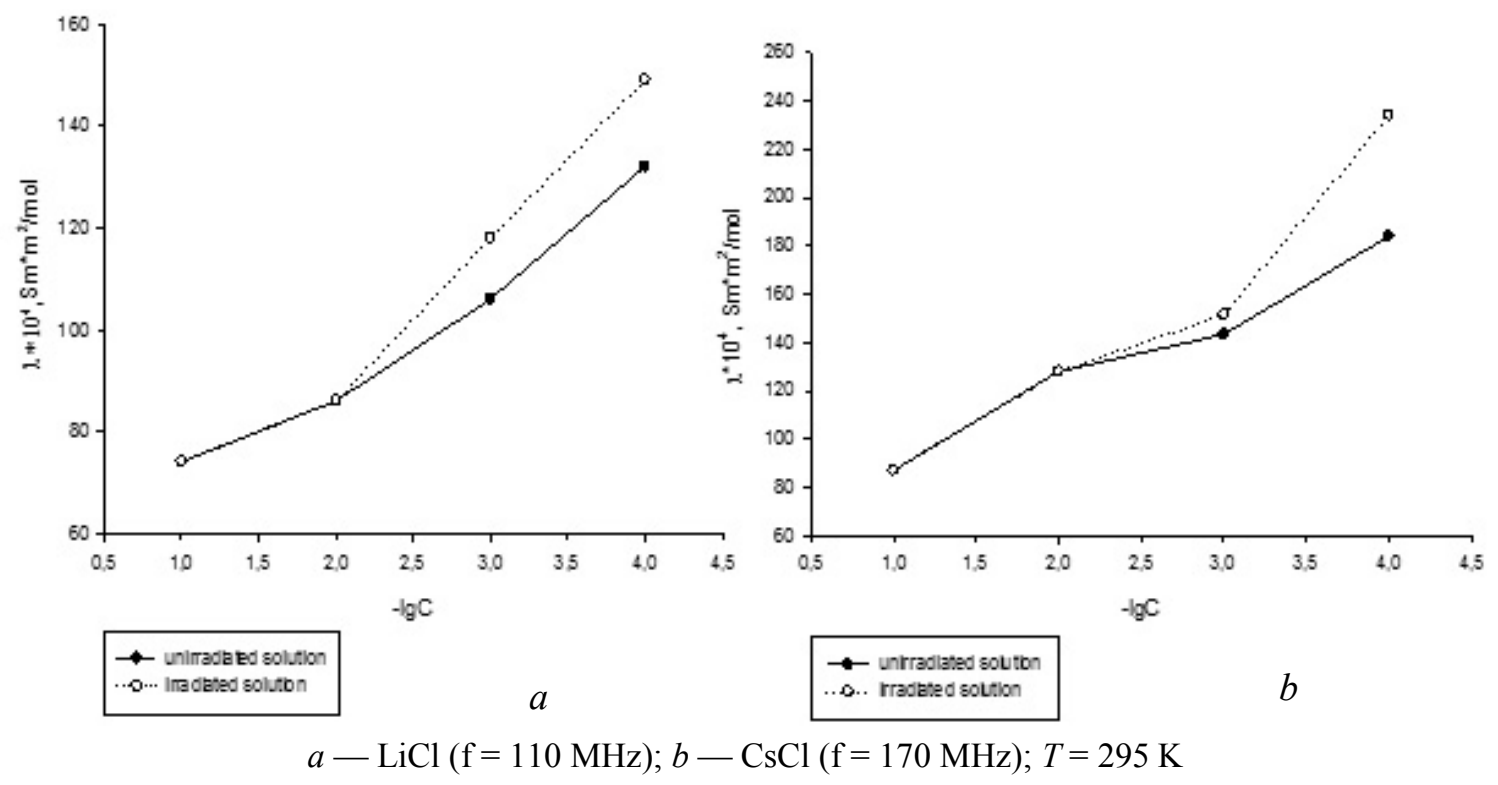

Figure 4. The dependence of the molar conductivity on the concentration 
It is established that, as in the case of water, the electrical conductivity of the solutions increases gradually over 100-110 minutes of EMF impact. Further irradiation does not affect its magnitude (Fig. 5a). After the termination of the action, relaxation of the conductivity to the initial value is observed (Fig. $5 b$ ), however, the relaxation time is a little longer than the time of the electrical conductivity increasing. It is 120 130 minutes. It should be noted that the electrical conductivity of irradiated water does not return to the initial value after the irradiation stops, but continues to increase for a week or more [7].
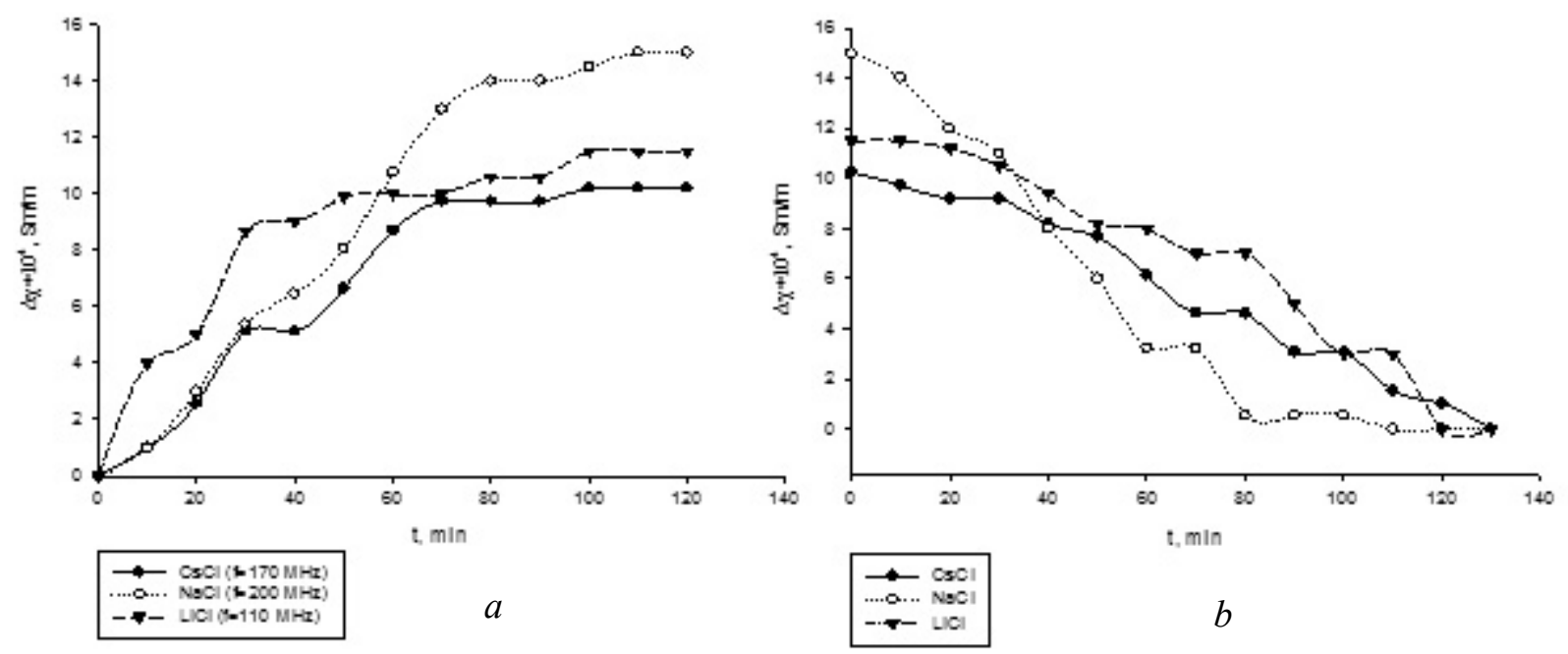

Figure 5 . The change in the electrical conductivity of $0.001 \mathrm{M}$ electrolyte solutions $\left(\mathfrak{x}_{\mathrm{f}}-\mathfrak{x}_{0}\right)$ as a function of the irradiation time $(a)$ and the time after irradiation $(b)$

Studies have shown that adding alcohols to water leads to an increase in its electrical conductivity. Table 2 gives data on the electrical conductivity of propanol-1 and butanol-1 solutions of various concentrations. It follows from the presented data that with the elongation of the hydrocarbon radical, there is slower increasing of the electrical conductivity.

Table 2

Electrical conductivity of aqueous solutions of propanol-1 and butanol-1 as a function of concentration at $T=296 \mathrm{~K}$

\begin{tabular}{|l|c|c|c|c|c|c|}
\hline$C, \mathrm{~mol} / \mathrm{L}$ & 0 & 0.025 & 0.05 & 0.10 & 0.15 & 0.20 \\
\hline $\mathfrak{x} \cdot 10^{4}, \mathrm{~S} / \mathrm{m}$, propanol-1 & 1.25 & 1.73 & 2.09 & 2.29 & 2.61 & 3.21 \\
\hline $\mathfrak{2} \cdot 10^{4}, \mathrm{~S} / \mathrm{m}$, butanol-1 & 1.25 & 1.48 & 1.79 & 2.14 & 2.75 & 2.81 \\
\hline
\end{tabular}

The influence of EMF leads to an increase in the conductivity of alcohols aqueous solutions. The effect is noticed only for certain field frequencies. Thus, the maximum increase in the electrical conductivity of the solution of butanol-1 is observed under the influence of EMF at a frequency of 130 and $170 \mathrm{MHz}$ and is $54 \%(170 \mathrm{MHz})$ at an irradiation time of 60 min (Fig. 6).

Increase in electrical conductivity during EMF influence occurs gradually. Its significant growth is observed in the first 30 minutes of EM impact. With further irradiation, a less noticed increase is observed. However, in 2 hours of irradiation, the value of the specific electrical conductivity became twice as high as its original value (Fig. 7a). After the field effect was stopped, the electrical conductivity of the solution was measured every day for 10 days. The electrical conductivity continued to increase and reached $11.6 \cdot 10^{-4} \mathrm{~S} / \mathrm{m}$ (Fig. $7 b$ ). In the further time there were no changes. The relaxation effect was absent for 6 months. A similar picture is observed for propanol-1.

Hexanol is slightly soluble in water. Its saturated solution corresponds to a concentration of $0.03 \mathrm{~mol} / \mathrm{L}$. Studies were carried out with solutions of precisely this concentration. Tables 3 and 4 show the electrical conductivity of the hexanol solution and its variation as a function of the frequency and time of EMF influence. 


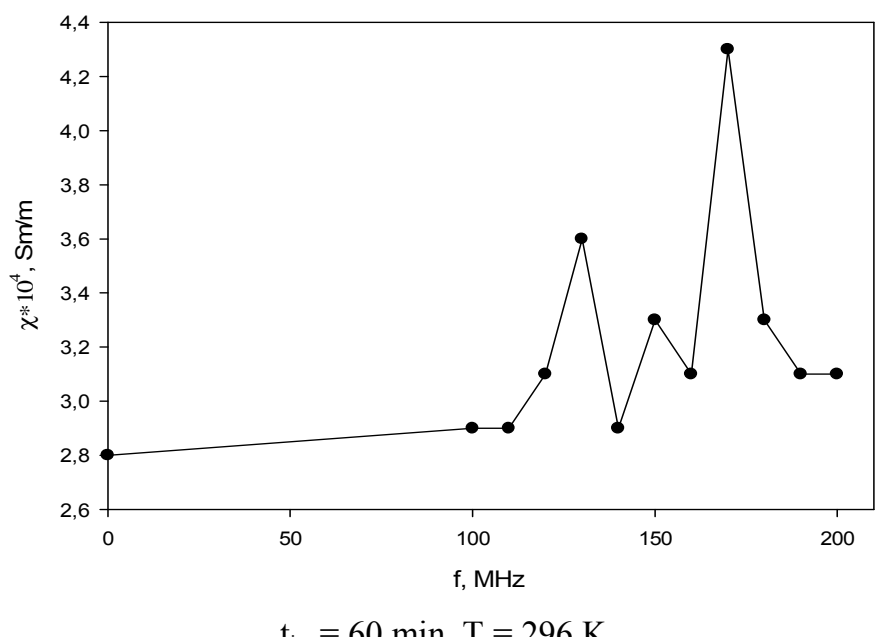

Figure 6 . The change in the specific electric conductivity of a $0.2 \mathrm{M}$ butanol-1 solution as a result of the influence of different frequencies EMF

Table 5 presents the values of the relative electrical conductivity of water and alcohols solutions $\mathfrak{x}_{\mathrm{r}}=\mathfrak{x}_{\mathrm{f}} / \mathfrak{x}_{0}\left(\mathfrak{x}_{\mathrm{f}}\right.$ is the specific electrical conductivity of the irradiated solution, $\mathfrak{x}_{0}-$ specific electrical conductivity of the non-irradiated solution), showing the effectiveness of the electromagnetic influence, depending on its frequency. For water and butanol, the maximum increase in electrical conductivity for a 30-minute impact time corresponds to a frequency of $170 \mathrm{MHz}$, and for propanol and hexanol it is $150 \mathrm{MHz}$. In the presence of alcohol, the degree of increase in $æ$ of water is lower.

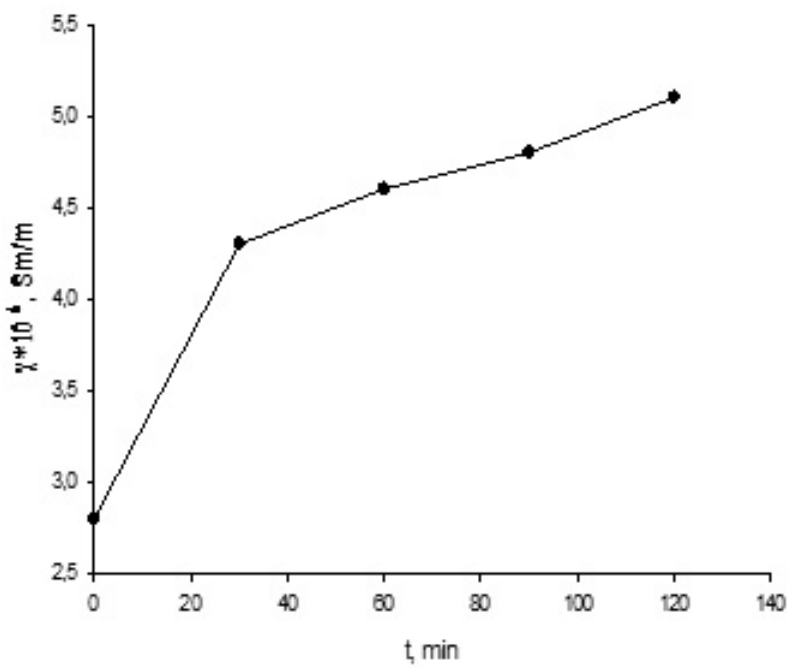

a

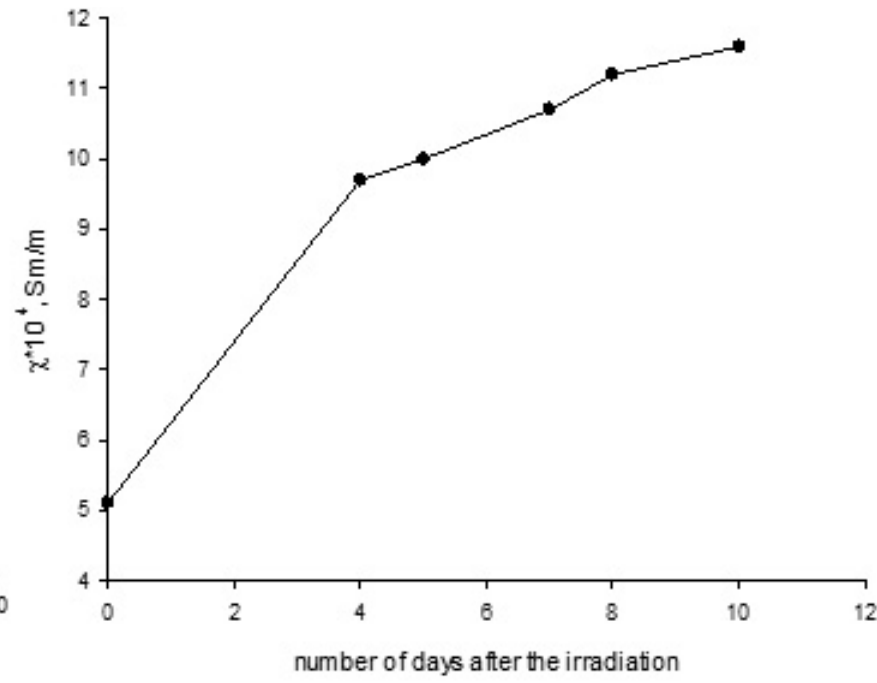

b

$a$ - on the time of irradiation; $b-$ on time after the irradiation; $\mathrm{f}=170 \mathrm{MHz}, \mathrm{T}=296 \mathrm{~K}$

Figure 7. The dependence of the specific electrical conductivity of a $0.2 \mathrm{M}$ butanol solution

Table 3

The changes in the electrical conductivity of a $0.03 \mathrm{M}$ hexanol aqueous solution as a result of the influence of different frequencies $\mathrm{EMF}\left(\mathrm{t}_{\mathrm{irr}}=\mathbf{3 0} \mathrm{min}, \mathrm{T}=\mathbf{2 9 6} \mathrm{K}\right)$

\begin{tabular}{|l|c|c|c|c|c|}
\hline $\mathrm{f}, \mathrm{MHz}$ & 0 & 130 & 150 & 155 & 170 \\
\hline $\mathfrak{x} \cdot 10^{4}, \mathrm{~S} / \mathrm{m}$ & 1.7 & 2.4 & 3.1 & 5.6 & 3.2 \\
\hline
\end{tabular}


The changes in the electrical conductivity of hexanol solutions as a function of the irradiation time $(f=170 \mathrm{MHz}, \mathrm{C}=0.03 \mathrm{M}, \mathrm{T}=296 \mathrm{~K})$

\begin{tabular}{|l|c|c|c|c|c|}
\hline $\mathrm{t}, \mathrm{min}$ & 0 & 30 & 60 & 90 & 120 \\
\hline$æ \cdot 10^{4}, \mathrm{~S} / \mathrm{m}$ & 1.7 & 3.2 & 3.8 & 4.1 & 4.3 \\
\hline
\end{tabular}

Table 5

The changes in the electrical conductivity of water and alcohols aqueous solutions as a result of the influence of different frequencies $\mathrm{EMF}\left(\mathrm{t}_{\mathrm{irr}}=\mathbf{3 0} \mathrm{min}, \mathrm{t}=\mathbf{2 9 8 \mathrm { K }}\right)$

\begin{tabular}{|l|c|c|c|c|}
\hline $\mathrm{f}, \mathrm{MHz}$ & 130 & 150 & 155 & 170 \\
\hline $\mathfrak{x}_{\mathrm{r}}$ water & 1.13 & 1.22 & 2.65 & $\mathbf{2 . 7 4}$ \\
\hline $\boldsymbol{x}_{\mathrm{r}}$ propanol-1 $(0,2 \mathrm{M})$ & 1.66 & $\mathbf{2 . 5 4}$ & 1.74 & 1.55 \\
\hline $\boldsymbol{\bigotimes}_{\mathrm{r}}$ butanol-1 $(0,2 \mathrm{M})$ & 1.29 & 1.18 & 1.28 & $\mathbf{1 . 5 4}$ \\
\hline $\mathfrak{x}_{\mathrm{r}}$ hexanol-1 $(0,03 \mathrm{M})$ & 1.39 & $\mathbf{2 . 0 6}$ & 1.46 & 1.88 \\
\hline
\end{tabular}

The increase in the conductivity of halides of salts solutions can be explained from the viewpoint of strengthening the structure of water as a result of electromagnetic influence. When the interaction energy of the water molecules increases, the interaction between them and the ions of the dissolved substance is weakened, so the degree of hydration of ions decreases. Since the mobility of the ions depends on their size, the ion, partially devoid of the hydrated shell, moves faster in the aqueous medium. This fact was confirmed in [17], where an increase in the diffusion coefficients of heavy metal ions as a result of the field action is shown. It is obvious that for the $\mathrm{K}^{+}$and $\mathrm{Cs}^{+}$ions with negative hydration the effect should appear to the minimum degree, which was experimentally detected (Fig. 2). This assumption seems to be contradicted by the data presented in Figure 3, where the maximum increase in electrical conductivity is observed in the presence of $\mathrm{Cs}^{+}$ions. However, at an electrolyte concentration of $10^{-4} \mathrm{~mol} / \mathrm{L}$, the electrical conductivity of its solution is comparable to the conductivity of water, and the experimentally recorded increase in it can be the consequence of the increase in the electrical conductivity of water, rather than the mobility of cesium ions. An increase in the electrical conductivity of water can be the result of a change in its structural organization, which changes the activation energy of the proton hopping from one position to another during the relay mechanism of water conductivity.

Since the acid properties of alcohols are less than in water, the observed increase in the electrical conductivity of their aqueous solutions can be due only to an increase in the mobility of hydrogen and hydroxyl ions formed as a result of partial dissociation of water molecules. As follows from the literature data [14], alcohols regulate the water structure as a result of hydrophobic hydration, which facilitates the movement of protons and hydroxyl ions along the hydrogen bond network. Hydrophobic hydration is the effect of interaction of nonpolar molecules or groups with the initial or transformed aqueous tetrahedral network. The most common case of hydrophobic hydration is solutions of substances, such as alcohols, whose molecules are heterofunctional. As follows from [2, 3], the hydrocarbon groups of alcohol molecules are located in the voids of the water structure, while the hydroxyl groups are integrated in the network of its hydrogen bonds. Stabilization of the water structure is primarily determined by the strengthening of hydrogen bonds near nonpolar groups, which is equivalent to lowering the water temperature. According to Anderson and Simons[18], the presence of tertiary butanol in water at a concentration of 0.06 mole fraction exerts the same effect on its lattice as a decrease in temperature by $15^{\circ} \mathrm{C}$. In the opinion of the authors of $[5,6]$, the introduction of dissolved non-electrolyte molecules into the water lattice leads to its complete restructuring and hardening of the water structure. Glew et al. [19] concluded that dilute aqueous solutions at low temperatures consist of molecules of a solute stabilizing the attached water and ordered hydrogen-bonded cells. This structuring of the solution, in the opinion of these authors, is the fundamental reason for the anomalous concentration dependence of enthalpy, heat capacity, sound absorption rate, solubility of inert gases, etc.

It can be assumed that the energy of the electromagnetic field absorbed by the solution is expended on strengthening the hydrogen bonds between water molecules. In the presence of alcohol, due to hydrophobic interactions, water is already partially structured, so the effectiveness of the field effect is lower. The iondipole interaction in electrolyte solutions is even stronger, so the energy of the electromagnetic field is sufficient to overcome it, only in extremely dilute solutions. 
A distinctive feature of the field influence on water, aqueous solutions of alkali metal salts and alcohols is also the fact that after termination of field influence the electrical conductivity of saline solutions slowly relaxes to the initial values, and the electrical conductivity of water and alcohol solutions continues to increase throughout the week, maintaining its increased value over the 6 months and more. If the first effect can be explained by the thermal motion impact, which destroys the structure of the electrolyte solution changed as a result of the EMF influence, then the «aftereffect» is much more difficult to explain. Since water is not an absolutely pure liquid, it always contains a certain amount of dissolved gases, it can be assumed that as a result of EMF influence, not only changes in the structural organization of water occur, but also its degassing. The theory of degassing of water under the EMF influence was developed by Shatalov [20]. From the viewpoint of this theory, some experimental facts can be explained. The process of formation of gas bubbles and their reverse sedimentation proceed slowly enough. Gas bubbles adsorb on their surface ions, present in small amounts in water. When these bubbles are removed from the volume of the aqueous medium, desorption of the ions occurs, which increases the electrical conductivity of the water. In salt solutions, the solubility of gases decreases, and the effect of the field influence is much lower. However, this theory does not explain why in the presence of dissolved substances the maximum change in the electrical conductivity of water depends on the nature of the dissolved substance. Therefore, the «after effect» needs further careful study to identify its nature.

\section{Conclusions}

Thus, the research has shown that at the influence of an electromagnetic field the electrical conductivity of water changes to the greatest degree. Additions of electrolytes or non-electrolytes reduce the effectiveness of electromagnetic interference. The influence of EMF on the electrical conductivity of electrolytes solutions is to a much lesser degree as compared with alcohols solutions and increases with dilution of solutions. The effect of increasing the electrical conductivity disappears even at an electrolyte concentration $\mathrm{C} \geq 0.01 \mathrm{~mole} / \mathrm{L}$, while for non-electrolytes solutions it is significant at a concentration of $0.2 \mathrm{~mol} / \mathrm{L}$ and is close in magnitude to the effect of the field influence on pure water.

\section{References}

1 Мокроусов Г.М. Физико-химические процессы в магнитном поле / Г.М. Мокроусов, Н.П. Горленко. — Томск: Издво ТГУ, 1988. - 128 с.

2 Классен В.И. Омагничивание водных систем / В.И. Классен. - М.: Химия, 1982. - 128 с.

3 Рахманин Ю.А. Вода - космическое явление / Ю.А. Рахманин, В.К. Кондратов. — М.: РАЕН, 2002. — 402 с.

4 Segtnan V.H. Studies on the structure of water using two-dimensional near-infrared correlation spectroscopy and principal component analysis / V.H. Segtnan, S. Sasic, T. Isaksson // Analitical Chem. — 2001. — Vol. 73, No.13. — P. 3153-3161.

5 Portier C.J. Assessment of Health Effects from Exposure to Power-Line Frequency Electric and Magnetic Fields / C.J. Portier, M.S. Wolfe. — USA: NIH Publ., 1998. - 67 p.

6 Гапочка Л.Д. Воздействие электромагнитного излучения КВЧ- и СВЧ-диапазонов на жидкую воду / Л.Д. Гапочка, М.Д. Гапочка, А.Ф. Королев // Вестник МГУ. Сер. Физика, астрономия. — 1994. — Т. 35, № 4. — С. 71-76.

7 Бучаченко А.Л. Химия на рубеже веков. Свершения и прогнозы / А.Л. Бучаченко // Успехи химии. — 1999. — Т. 68, № 2. - С. 99-118.

8 Киргинцев А.Н. К вопросу о влиянии магнитного поля на физико-химические свойства растворов / А.Н. Киргинцев, В.М. Соколов, В.И. Ханаев // Журнал физической химии. — 1968. - Т. 48. — С. 301-303.

9 Красиков Н.Н. Действие электромагнитного поля на жидкости, осуществляемое без контакта с потенциалозадающими электродами / Н.Н. Красиков, О.В. Шуваева // Журнал физической химии. — 2000. — Т. 74, № 6. — С. 1133-1135.

10 Лобанов А.И. Параметрический резонанс и формирование диссипативных структур в растворах электролитов при воздействии периодического электрического поля / А.И. Лобанов, Т.К. Старожилова, А.П. Черняев // Журнал физической химии. - 2000. - Т. 74, № 11. - С. 2087-2092.

11 Красиков Н.Н. Влияние электрического поля на ионный состав водных растворов / Н.Н. Красиков // Журнал физической химии. - 2002. - Т. 76, № 3. - С. 567-568.

12 Самойлов О.Я. Структура водных растворов электролитов и гидратация ионов / О.Я. Самойлов. - М.: Изд-во АН CCCP, 1957. - 144 c.

13 Белоусов В.П. Термодинамика водных растворов неэлектролитов / В.П. Белоусов, М.Ю. Панов. — Л.: Химия, 1983. -264 c.

14 Крестов Г.А. Термодинамика процессов в растворах / Г.А. Крестов. - Л.: Химия, 1984. — 272 с.

15 Бессонова А.П. Частотная дисперсия физико-химических свойств воды, подвергшейся ЭМ воздействию / А.П. Бессонова, И.Е. Стась // Известия вузов. Химия и химическая технология. -2010 . — Т. 53, № 4. - С. $48-50$. 
16 Стась И.Е. Влияние электромагнитного поля на величину адсорбции спиртов из водных растворов / И.Е. Стась, В.Ю. Чиркова // Известия АлтГУ. - 2012. — Т. 2, № 3. - С. 138-141.

17 Стась И.Е. Электродные процессы в высокочастотном электромагнитном поле / И.Е. Стась, Б.П. Шипунов, Т.С. Ивонина // Известия вузов. Сер. Химия и хим. технология. - 2003. - Т. 45, № 5. - С. 61-66.

18 Anderson R.C. Study of the influence of the presence of alcohols on water structure / R.C. Anderson, M.C.R. Simons // Trans. Faraday Soc. - 1969. - Vol. 65, No.10. - P. 2550-2557.

19 Glew D.N. Hydrogen-Bonded Solvent Systems / D.N. Glew, H.D.Mak; Ed. by A.K. Covington \& P. Jones. — London, United Kingdom, 1968. - 264 p.

20 Шаталов В.М. Дегазация биожидкостей как механизм биологического действия слабых электромагнитных полей / B.М. Шаталов // Біофізичний вісник. - 2009. - Т. 23, № 2. - С. 74-86.

\author{
И.Е. Стась, В.Ю. Чиркова, И.А. Штоббе
}

\title{
Сілтілі металл хлоридінің су, сумен араластырған және спирттің электрөткізгіштігі және оның электрмагниттік өрістері әсерінен өзгеруі
}

\begin{abstract}
Мақала жоғары жиілік электрмагнитті өрістің су, сілтілі металл хлоридтің сулы ерітінділердің құрылымды спирттік электрөткізгіштігіне әсерін зерттеуге арналған. Су ерітінділері мен су электрөткізгіштігі 100-200 МГц аралағында электромагнитті өріспен әсер еткенде су және сулы ерітінділердің электрөткізгіштігі едәуір өсетіні байқалады. Электрмагниттік ықпалдың тиімділігі өріс жиілігі мен оған әсер ету уақытынан тәуелді. Яғни, су және су ерітінділері электрөткізгіштігі екі есеге артады. 0,01 моль/л аз мөлшердегі ерітіндіде өріс тиімділігі көрініс табады және хлорид натриі ерітіндісінде $10^{-4}-10^{-3} \mathrm{M}$ электрөткізгіштік едәуір жоғарылап, 27-33 \% құрайды. Әсерді тоқтатқан жағдайда электролит ерітінділері электрөткізгіштігі өз бастапқы мәндеріне болады, ал су мен спиртті ерітінділерінің электрөткізгіштігі 7-10 күн аралығында артады. Байқалған құбылыстарды суқұрылымының өзгерісімен түсіндіруге болады.
\end{abstract}

Кілт сөздер: су, су ерітінділері, сілтілі металл хлоридтері, спирттердің су ерітінділері, электрөткізгіштік, электрмагниттік өріс, жиілік, сәулелену уақыты.

\author{
И.Е. Стась, В.Ю. Чиркова, И.А. Штоббе \\ Электропроводность воды, разбавленных водных растворов \\ хлоридов щелочных металлов и спиртов и ее изменение \\ в результате воздействия электромагнитного поля
}

\begin{abstract}
Статья посвящена изучению влияния высокочастотного электромагнитного поля на электропроводность воды, водных растворов хлоридов щелочных металлов и разбавленных водных растворов спиртов нормального строения. Установлено, что при воздействии электромагнитного поля с варьируемой в диапазоне 100-200 МГц частотой наблюдается значимое увеличение электропроводности воды и водных растворов. Эффективность электромагнитного воздействия зависит от частоты поля и времени его воздействия. В наибольшей степени возрастает электропроводность воды и водных растворов спиртов - более, чем в два раза. Эффект полевого воздействия на растворы электролитов проявляется лишь при концентрации раствора, меньшей 0,01 моль/л, и выражен в меньшей степени - максимальное увеличение электропроводности наблюдается в $10^{-4}-10^{-3} \mathrm{M}$ растворах хлорида натрия и составляет 27-33\%. После прекращения воздействия электропроводность растворов электролитов медленно релаксирует к исходным значениям, а электропроводность воды и водных растворов спиртов продолжает возрастать на протяжении 7-10 дней до установления стационарного значения. Наблюдаемые явления могут быть обусловлены изменением структурной организации воды в результате электромагнитного воздействия.
\end{abstract}

Ключевые слова: вода, водные растворы, хлориды щелочных металлов, водные растворы спиртов, удельная электропроводность, электромагнитное поле, частота, время облучения.

\section{References}

1 Mokrousov, G.M., \& Gorlenko, N.P. (1988). Fiziko-khimicheskie protsessy v mahnitnom pole [Physicochemical processes in a magnetic field]. Tomsk: Tomsk State Univ. Publ. [in Russian].

2 Klassen, V.I. (1982). Omahnichivanie vodnykh sistem [Magnetization of water systems]. Moscow: Khimiia [in Russian]. 
3 Rahmanin, Yu.A., \& Kondratov, V.K. (2002). Voda - kosmicheskoe yavlenie [Water is a cosmic phenomenon]. Moscow: RAEN [in Russian].

4 Segtnan, V.H., Sasic, S., Isaksson, T., \& Ozaki, Y. (2001). Studies on the structure of water using two-dimensional nearinfrared correlation spectroscopy and principal component analysis. Analitical Chem., 73(13), 3153-3161.

5 Portier, C.J., \& Wolfe, M.S. (1998). Assessment of Health Effects from Exposure to Power-Line Frequency Electric and Magnetic Fields. USA: NIH Publ., 67.

6 Gapochka, L.D., Gapochka, M.D., \& Korolev, A.F. (1994). Vozdeistvie elektromahnitnoho izlucheniia KVCH- i SVCHdiapazonov na zhidkuiu vodu [Effect of electromagnetic radiation of EHF- and microwave ranges on liquid water]. Vestnik MGU. Ser. Fiz. Astron. - Herald of Moscow University. Ser. Phys. and Astron., 35(4), 71-76.

7 Buchachenko, A.L. (1999). Khimiia na rubezhe vekov. Sversheniia i prohnozy [Chemistry at the turn of the century. Accomplishments and forecasts]. Uspekhi khimii-Successes of chemistry, 68, 2, 99-118 [in Russian].

8 Kirgincev, A.N., Sokolov, V.M., \& Hanaev, V.I. (1968). K voprosu o vliianii mahnitnoho polia na fiziko-khimicheskie svoistva rastvorov [To the question of a magnetic field influence on the physicochemical properties of solutions]. Zhurnal fizicheskoi khimii - Journal of Phys. Chem., 48, 301-303 [in Russian].

9 Krasikov, N.N., \& Shuvaeva, O.V. (2000). Deistvie elektromahnitnoho polia na zhidkosti, osushchestvliaemoe bez kontakta s potentsialozadaiushchimi elektrodami [The influence of an electromagnetic field on a liquid, realized without contact with potentialsetting electrodes]. Zhurnal fizicheskoi khimii - Journal of Phys. Chem., 74, 6, 1133-1135 [in Russian].

10 Lobanov, A.I., Starozhilova, T.K., \& Chernyaev, A.P. (2000). Parametricheskii rezonans i formirovanie dissipativnykh struktur v rastvorakh elektrolitov pri vozdeistvii periodicheskoho elektricheskoho polia [Parametric resonance and the formation of dissipative structures in electrolyte solutions under the action of a periodic electric field]. Zhurnal fizicheskoi khimii - Journal of Phys. Chem., 74, 11, 2087-2092 [in Russian].

11 Krasikov, N.N. (2002). Vliianie elektricheskoho polia na ionnyi sostav vodnykh rastvorov [Influence of the electric field on the ionic composition of aqueous solutions]. Zhurnal fizicheskoi khimii - Journal of Phys. Chem., 76, 3, 567-568 [in Russian].

12 Samoylov, O.Ya. (1957). Struktura vodnykh rastvorov elektrolitov i hidratatsiia ionov [Structure of aqueous solutions of electrolytes and hydration of ions]. Moscow: Izdatelstvo AN SSSR [in Russian].

13 Belousov, V.P., \& Panov, M.Yu. (1983). Termodinamika vodnykh rastvorov neelektrolitov [Thermodynamics of aqueous solutions of non-electrolytes]. Leningrad: Khimiia [in Russian].

14 Krestov, G.A. (1984). Termodinamika protsessov v rastvorakh [Thermodynamics of processes in solutions]. Leningrad: Khimiia [in Russian].

15 Bessonova, A.P., \& Stas', I.E. (2010). Chastotnaia dispersiia fiziko-khimicheskikh svoistv vody, podverhsheisia EHM vozdeistviiu [Frequency dispersion of physico-chemical properties of water exposed to EM impact]. Izvestiia vuzov. Khimiia $i$ khimicheskaia tekhnolohiia - Reviews of HEI. Chemistry and chemical technology, 53, 4, 48-50 [in Russian].

16 Stas', I.E., \& Chirkova, V.Yu. (2012). Vliianie elektromahnitnoho polia na velichinu adsorbtsii spirtov iz vodnykh rastvorov [Influence of the electromagnetic field on the amount of adsorption of alcohols from aqueous solutions]. Izvestiia AltGU - Reviews of Altay State University, 2, 3, 138-141 [in Russian].

17 Stas', I.E., Shipunov, B.P., \& Ivonina, T.S. (2003). Elektrodnye protsessy v vysokochastotnom elektromahnitnom pole [Electrode processes in a high-frequency electromagnetic field]. Izvestiia vuzov. Ser. Khimiia i khim. tekhnolohiia - Reviews of HEI. Chemistry and Chemical Technology, 45, 5, 61-66 [in Russian].

18 Anderson, R.C., \& Simons, M.C.R. (1969). Study of the influence of the presence of alcohols on water structure. Trans. Faraday Soc., 65(10), 2550-2557.

19 Glew, D.N., \& Mak, H.D. (1968). Hydrogen-Bonded Solvent Systems. A.K. Covington and P. Jones (Eds.). London, United Kingdom.

20 Shatalov, V.M. (2009). Dehazatsiia biozhidkostei kak mekhanizm biolohicheskoho deistviia slabykh elektromahnitnykh polei [Degassing of biofluids as a mechanism of the biological effect of weak electromagnetic fields]. Biofizichnii visnik - Biophysical bulletin, 23, 2, 74-86 [in Russian]. 